\title{
Legal Principles Governing the Production and Distribution of Blood
}

\author{
Maryam Ahmadi Partovi ${ }^{1} \&$ Fereidoon Nahreini ${ }^{1}$ \\ ${ }^{1}$ Department of Law, Kish International Campus, University of Tehran, Kish, Iran \\ Correspondence: Maryam Ahmadi Partovi, Kish International Campus, Department of Law, Kish International \\ campus, University of Tehran, Kish, Iran. E-mail: ah madipartovi@ut.ac.ir
}

Received: June 18, 2016 Accepted: July 9, 2016 Online Published: July 31, 2016

doi:10.5539/jpl.v9n6p29 URL: http://dx.doi.org/10.5539/jpl.v9n6p29

\begin{abstract}
Use of blood and its derivatives has a special place in ensuring the health of citizens. In recent years, due to risk of transfusion-transmitted infections, followed by risk of serious and incurable diseases such as for people in need AIDS, hepatitis B, C and etc., consumers have been prompted to refer to the courts for litigation and justice. It should be noted that the state, as an exercise of sovereignty and trustee of the exclusive production and distribution of blood products, produce commodities with inevitable insecurity. In this regard, it must observe safety obligations and provide information and warnings to the public in relation to the delayed complications of transfusion medicine. According to existing laws, law doctrine, and judicial procedures, Blood Transfusion Organization and the Center for Blood Research and Fractionation are working under the supervision of the Ministry of Health and Medical Education. In the case of failure tocompliance with the obligations, the state is obliged to compensate the physical, moral, and material damages to victims despite the governmental nature of action, article 11 of the law of civil liability, and in relation to the State Immunity to compensate for the loss of the exercise of sovereignty. Thus, it is possible to execute justice for these people through the legal courts based on the inherent competence of the courts in form of complaint according to additional and exceptional competence of criminal authorities.
\end{abstract}

Keywords: civil liability, blood products, compensation

\section{Introduction}

In the distant past, especially among Arabs and in the days of ignorance, there was no common way to use blood except drinking. According to many verses from the Holy Quran such as Al-Maeda verse 3, Anam verse 145, Nahl verse 115, many jurists insist on the tradition, and traditions on the sanctity of blood and the prohibition of eating blood (Ismaili, 1994, p. 149). Since they did not know any rational-lawful benefit for buying and selling blood, it was regarded illegal in terms of possession, trade, and business. With the advancement of knowledge and the various uses of blood, particularly hu man blood and its products, this material has found a particular and vital role. Thus, buying and selling blood has been excluded from the in stances of illegal trades. Not only its trading is permitted by Muslim jurists but also its exchange is conditioned to a non-financial gift. Therefore, criteria for the permissibility of sales in the blood is having the possession and having rational lawful benefit. Buying and selling blood to eat is forbidden. Its mere najāsa is not the reason for the sanctity of buying and selling; there is no illegality to buy and sale a najis object. Although we have witnessed dramatic improvements in the supply of blood products in the past few decades, contamination and viral diseases caused by products as well as the number of at risk citizens have been so prevalent that life and human health is constantly at risk. In this regard, the state has taken some measures to interfere and control the production and distribution of blood products. By taking proprietary production process, the government seeks to protect the health of its citizens. According to former ideas, the state was authorized to act for any kind of work; if a damage was imposed on an individual, it was ignored due to the sanctity of the state. There is no doubt that a state can have the right and obligation due to civic responsibility as a legal entity of public law like natural persons. With these lines, the objectives of this research are: (1) explaining the basis of non-contractual liability of the state in the production and distribution of blood products; (2) explaining the need to compensate for individuals who are suffering from viral diseases because of blood transfusion.

\section{The Production of Blood Derivati ves and Related Parties}

Blood is a sacred substance; its sanctity has been remained from the mythological to present time. World War II 
and the Vietnam War, with all atrocities and cruel killings, gave the opportunity to save lives of thousands war wounded. Then, institutes of blood transfusions and blood products were established; hospitals were equipped to develop a blood transfusion ward (Noori, 2001, p. 82). Each product must be tailored to the patient's prescription because blood is not a simple matter and contains a variety of antigens and antibodies, different proteins and other elements that each can lead to adverse reactions in the recipient (Noori, 2001, pp. 4-5). Any therapeutic material obtained from human blood is called blood product. A variety of blood products can be achieved with different therapeutic applications from blood. Since blood transfusion is a tissue graft from a donor to a recipient, there is always the possibility of infection transmission caused by blood transfusion and immunological responses to non-self cells or plasma proteins to recipient (Noori, 2001, p. 82). The World Health Organization recommends that all donated blood should be screened for HIV, hepatitis B and hepatitis C. Many countries do not have reliable experimental mechanis ms due to labor shortages, lack of basic laboratory services, poor quality laboratory equipment, as well as irregular blood gathering (Adibi Motlaq, 2007, p. 156). Before 1955, blood transfusion was scattered in different hospitals; there is no reliable evidence in this regard. In the field of blood products preparation, Army Blood Center began to prepare cellular and plasma products on limited scale since 1961. In the same years, it began to refine plasma and prepare its products in collaboration with the Pasteur Institute of Iran. With the establishment of Iranian Blood Transfusion Organization in 1974, perennial efforts came to fruition and blood transfusion in Iran became regulated. Following the general revision of the state budget in 1979, Blood Transfusion Organization became a government organization affiliated to the Ministry of Health and subject to general governmental regulations. In 1984, Iranian Blood Transfusion Organization Statute was adopted and Blood Transfusion Organization was regarded as the only custodian of blood supply and blood products in Iran. Before 2008, Blood Research and Purification Center, as a subset of the Blood Transfusion Organization, was responsible for the production of blood products. In 2008, it was emerged as an independent legal personality with the independent responsibility and obligations. The company's products are divided into two groups of plasma-derived drugs and laboratory reagents on a limited basis. At present, Blood Transfusion Organization is only decision-making body in the supply and distribution of safe blood and blood products in Iran; all decisions related to blood products are concerned directly to this organization (Mohammad Khani, 2007, p. 98).

\section{Civil Liability and Compensation System}

Liability has been defined in civil rights as, "One's legal commitment to removing the loss he has caused to another person either it has been intentionally or due to his actions." The term Zeman (meaning liability) has been used for this word; it refers to any type of responsibility including financial liability criminal liability (Jafari Langroodi, 2001, p. 642). According to Arabic and Islamic traditions, it means to be held accountable and punished for performing or refraining from doing something; it is equivalent for 'duty' and 'competence' (Bad ini, 2005, pp. 28-29). In Islamic law, 'liability'has been used for undertaking, binding and acting minister of somebody; the binding is both financial and criminal (Jafari Langroodi, 2001). Hu man beings are created free and authorized. The authority and governance of reason makes a man accountable for actions; he can be questioned or be blamed (Dalvand, 2007, p. 17). In legal terms, it is a person's accountability for actions conventionally attributed to him. Its legal enforcements are different depending on the type of liability (Barikloo, 2006, p. 22).

In terms of contractual liability and civil liability, the common point in these two liabilities is provision of suffered damages and the issue that one who is accountable for the loss should try to compensate for it. Proving guilt in any of these two conditions is not a condition (Jafaritabar, 2010, p. 77). Contractual liability is commitment arises as a result of violating the provisions of private contracts (Safari, 1998, p. 13). It can be said that a liability is contractual in the event that the following conditions are met; pre-contractual liability is a kind of civil liability (Katouzian, 2007, p. 72). In addition, if the loss occurs after the completion of contract, or the contract is void, liability is not contractual (Hosseini Nejad, 1998, p. 17). Breach of contract may be in the form of omission (not doing the obligation), performing the action by delay or outside the framework of the contractual terms and conditions (Jafari Langroodi, 1999, p. 643). It is sometimes possible that obligations may be imposed on the obligee of the contract in accordance with law, custom or implied conditions; any failu re will lead to contractual liab ility (Shahidi, 2004, p. 32). According to this condition, damage must be caused by breach of contract, or contractual breach. However, if damage is not caused by the contract, civil liability will be provided by its provisions (Jourdain, 2007, pp. 17-18). Legally, not only natural persons are responsible bu also legal persons are responsible for their actions whether they are private law also legal persons or public law also legal persons. These spiritual phenomena represent their will through institutions such as boards, councils, and administrators. Thus, their actions have the capability to be assigned to them. It is important that the imp lications 
of guilt changes in different time periods; it has gradually loses its moral implication and it has found a social and 'in abstracto' implication. The best criterion is consideration of a reasonable and prudent person in the circu ms tances. Nowadays, jurisprudence, doctrine and some rules consider criminal liability for legal pe rs ons; it is imagined in form of dissolution, confiscation of property, fines, sentencing and...; therefore, it is not logical to confirm criminal liability of legal persons but regarding his civil liability far (Akbari, 2005, pp. 17-18). Consequently, all legal persons are responsible for compensation in case of harming others; there is no difference between natural person and legal person in this sense (Safaei \& Ghasemzadeh, 2001, pp. 170-171).

\section{Elements of Civil Liability}

The subject of civil liability is compensation for loss or damage; civil liability is subject to disproof as long as losses are not met. Existence of loss is condition for civil liability. Loss is any shortcomings and defects imposed on the property, equity, body, reputation, fame, or personal feelings unfairly, unintentionally, and illegal to another party (Naini, 1997, p. 378). Every damage is not legally repairable but only some damages with particular conditions are repairable. In case of meeting all conditions, one can expect compensation (Mehman Navazan, 2009, p. 83). Body or physical loss means any damage and defects to a person's physical integrity. Th is type of loss is limited to natural persons because legal person has not objective, real, and tangible existence and his existence is relative (Barikloo, 2006, p. 69). Since the system of physical damage compensation has been separated from the system of financial damage compensation and considering Article 1 and 5 of Civil Code, according to some jurisprudential principles such as sire ughala (ways of the wise), no damage rule, denial of hardship, causation, and current judicial procedures damage beyond atonement is compensatory. Atonement should not be regarded as a fix a mount to let the inju red to request for higher amount when he can prove the case. It should be said that proving an object do not prove exceptional cases (Badini 2005, pp. 332, 336, 341-342). The exact amount has been set for atonement as the minimum amount of harm (Mohammad Pour, 1997, p. 52); atonement represents the least amount of loss and its surplus can be paid under the rules of jurisprudence and law (Katouzian, 2007, p. 290). As an injured person can request for compensation by both insurance and civil liability system, this is not contrary to the principle of prohibition of several compensation for losses. In case of proving more loss, the injured can apply for surplus compensation than atonement according to the rules of civil liability (Badini, 2008, p. 61; Katouzian, 1992, pp. 26-28). In this way, all unfair losses should be compensated (Akhavi \& Kashani, 2001, p. 56). It should not be regarded as double recovery compensation.

\section{The System of Victim's Remedy}

Due to the many government facilities and financial resources at its disposal, it has a considerable portion in compensation. When the governments are responsible for compensation, they may refuse to compensate by several excuses. In this regard, the principle os damage governmental co mpensation has been predicted (Ashoori, 1997, pp. $39 \&$ 80-81). Islam has emphasized in numerous occasions on the liability of the treasury and the protection of Muslim blood. There are many cases in jurisprudential texts in which the governor is responsible for paying blood money. In other words, the government, as a legal person, can pay from its assets to compensate for losses. The oldest religious texts argue that the liability is equal when some factors have been the cause of damage (Seraj, 1989, p. 189). It says that when two persons have an intentional crash and both die, each person is responsible for the half of other party's blood money; it should be paid from their assets because both have been effective in the death (Al-Terablosi 1991, p. 156). When two persons are effective in the emergence of a loss, Najafi believes that the liability should be divided equally and each party is responsible to pay half of the losses (Najafi, 1981, p. 63).

\section{Judicial Cases in Compensation of Moral Damages}

In addition to material damages and covering the costs of treating patients, it is possible to compensate for spiritual and mental damages to relieve victims since most of legal bases for claiming moral damages in Iran legal system (including Articles 167 and 171 of Iran Constitution law, Articles 58 and 698 of Iran Civil Code, Articles 1, 2, 8, 9, and 10 of Is lamic Penal Code ,paragraph 2 of Article 9 of Law on Code of Criminal Procedure (1911) enforseable in military courts and recently article 14 of criminal procedure law(2013). Spiritual compensation has also been predicted in other laws such as Abuse of Trade Names, Commercial Code, Law on the Registration of Trademarks and Patents, Law on Protection of Authors and Artists, Press Law, and the Civil Code (Qasemzadeh, 2008, pp. 84-85). A lthough the subject of spiritual losses is immaterial and intangible and its financial compensation are incompatible with moral principles, it is not far to compensate for them because the spiritual loss has been occurred in reality (parvin, 2001, p. 183). The legislators have predicted two ways for compensating spiritual losses: financial and non-financial. Article 3 of Civil Liability Code stipulates, "The court shall determine the amount of loss, way and quality of its compensation with regard to the circumstances around 
the case." In this way, way and quality of its compensation is determined by judge. Article 10 of this law says, "Anyone whose personal or family prestige and credits have been damaged can seek compensation for the material and spiritual loss from the one who has inflicted the injury. Should the importance of loss and type of fault requires and in case that fault has been established, the court can rule, in addition to the is suance of a ruling for financial damages, for the removal of loss by other ways such as compelling the loss inflictor to apologize and publish the ruling in newspapers and the like."

\section{Ci vil Liability Lawsuit and Competent Authority}

There are different procedures and rules to make a claim and determine the elig ibility of authorities. Article 34 of Iran Constitution stipulates, "It is the indisputable right of every citizen to seek justice by recourse to competent courts. All citizens have right of access to such courts, and no one can be barred from courts to which he has a legal right of recourse." So me principles and procedures are essential for lawsuit pursuant to Article 1 of Code of Civil Procedure. Inherent competence of the court is an important issue in this regard because lawsuit is inevitable for the victim to seek compensation; competence of the court hearing a claim of civil liability is very important. Two ways are predicted for victims in this regard. First, a legal lawsuit of civil liability; second, criminal complaint and claim for damages caused by the offense. In jurisprudence on the case of proving a sentence, it is referred to some verses of Quran including verse 36 of Al-Ahzab that says, “...when Allah and His Messenger have decided an affair they should exercise their choice." Thus, sentenced cases are fix and permanent rules (Habibi, 2005, p. 62). Ru le of criminal sealed case prevents second rise of a criminal case; this rule does not prevent litigation for losses resulting from an offense" (Ashoori, 2007, p. 236-237).

\section{Legal Barriers to Governmental Civil Liability}

There are some points in civil liability in which the causal relationship between the offender and the loss is eliminated; in other words, porosity occurs in civil liability or the civil liability rules out automatically accord ing to the cause. This means of exemption from civil liability may be due to factors justifying the offense or due to the involvement of the external causes. The principle of "permission of an illegal action in the case of necessity" has an important role in the understanding of Islamic jurisprudence. It is known as emergency principle. With respect to this principle, one may ask about the fulfillment of emergency principle when a person is obliged to harm another person to remove a bigger loss. Ghazali states that all prohibitions will be permitted at the time of emergency; moreover, it is said that necessities eliminate legal obstacles (Golestani, 2007, p. 241). According to Raf' Hadith, the effects of 9 things have been removed from Muslim Umma. However, it is not true to argue that one expects disclaimer when he harm others. Nevertheless, the existence of danger, its imminent nature, and lack of better way to remove danger should be necessary and proportionate action being committed (Tavasoli Jahromi, 2003, p. 65). It is important to discern whether a conventional man commit such action in the case of exposing to the danger is very important; this attitude is seen in French Law. Investigation of judicial procedures in Iran indicates that few notable verdicts have been issued to explain the conceptual boundaries of governance and tenure. In this way, due to lack of a judicial precedent, the actions known by the government as exercise of sovereignty is unknown.

The idea of The General Assembly of the Supreme Court (1969) is an exceptional case that regards change one's nationality as exercise of sovereignty; hence, addressing petition for leaving citizenship is only authorized by Delegation of Ministers (Abulhamd, 1991, p. 824). Written judgment 78 to 1052 in branch 1060 of Tehran Public Court (15/07/2005) or the famous sentence on Hemophilia Case notes, "Nowadays, Government and even public organizations, interferes in all areas of social, economic, and social life of citizens and employs many technical and material means to advance programs." It talks about the need for massive government intervention while it is aware that there is the possibility of harming persons. In scientific, legal, logical, and moral code, it speaks of need to redress and determine state responsibility. The court's expression that state is only an executor, and his actions in foreign production and supply is not an exercise of sovereignty, is not justifiable. Some scholars believe that this idea refers to state tenure to refrain state's exemption from payment compensation according to Article 11 of Civil Liability Law (Seifi, 2005, p. 288). In order to partial or total freedom and escape from responsibility, prejudicial may assert that another factor has been effective in the emergence of loss and there is a casual relationship between the factor and loss; it is called an external factor. In other words, external cause is an event reducing or eliminating the casual relationship proved harmful act and the damage. If the casual relationship between external factor and loss is so strong that cuts the causation between the harmful act and loss, the defendant will totally be exempted from liability; but it only weakens the relationship and it proves that the loss has two causes, the external cause acts only as reducer of the responsibility scope (Sherafat Pey ma, 2007, pp. $82-95)$. 


\section{Conclusion}

In the past, no body talked about the benefits of blood; people believed that blood has no rational application and benefit due to its impure (najis) nature. Gradually, with regard to developments in contemporary society during the present era of industrialization, and improving the position this human product in medicine, its prohibition has been forgotten. Now, its benefits in saving human lives are the subject of discussion and scrutiny because the blood products may cause fatal damages apart from their health benefits. The incidence of new losses, but unpleasant, is very pain ful to the victims; every person may think about the ways to compensate for such losses. Despite medical advances and constructive role in the area of transfusion of blood products as well as the vital role of these products in the continuity of life in patients with thalassemia, he mophilia or patients requiring blood, avoiding effects of insecurity of blood derivatives seems impossible. Very heavy damages and losses caused to the the aggrieved person leads to deep and unbroken connection between medical medicine and law because law has the duty to retell the ele ments of civil liability through laws, rules and princip les and to announce the ways to compensate for losses imposed on the aggrieved person. Contrary to the only authoritative actions and performance by the government in the past and the idea of state's lack of responsibility, we are witn essing useful activities by this legal personality of public law in different areas because legal persons, the same as natural persons, can be subject to rights and duties; their involve ment in different commercial, industrial, medical and ... areas bring them some rights and commitments. According to the importance of preserving human life, in order to provide health and the interests of society, production and distribution of blood products are in the exclusive jurisdiction of the Blood Transfusion Organization and the Ministry of Health as the highest and the only source of blood supply according to the constitution and other laws. This trend may cause to very heavy damage to consumers and persons in need of blood. The question is whether the state has civil liability for the losses or whether supply of blood products is included in exercise of sovereignty. As law has not presented any clear standard to distinguish and separate usual actions and exercise of sovereignty, it should be regarded as an exercise of sovereignty according to attributes that have expressed professors of law, Civil Service Management Code, Law for Determination of Arbitration between Individuals and Govern ment, judg mental procedure, and Statute of the Blood Transfusion Organization (arguing that custodian of the blood supply does not receive any financial compensation, its services are free, and other people do not have the right to intervene in the process of production and distribution. Despite this exercise of sovereignty by the state according to sentences issued at courts, the government may have civ il liability and Blood Transfusion Organization is a govern mental institution. It is included in the three pillars of civil liability. In the case of meeting conditions of civil liability, the state will be bound to compensate for the aggrieved person. It should be noted that the state liability in this case is sheer liability in terms of damage. Legal precedent indicates that powerful institutions such as police, inspection agencies, and forensic organizations have been able to prove the fault of Blood transfusion Organization after a long time due to forces by legal authorities; thus, it seems far for an aggrieved person to have the ability to prove the fault by state. With regard to setting liability for the state and since the concept of fault is applied only for casual relationship, it should be accepted that production trustee must observe laws, regulations and standards in the Statute of the Blood Transfusion Organization, Law on the Organization and Duties of Health, and Medical Education Ministry, and Medical and Pharmaceutical Regulatory Affairs. Therefore, it is responsible for the safety its industrial products. Trusting to the powerful institution that has special financial facilities compared to other natural and legal persons, patients expect to receive healthy blood free from contamination. Safety pledge and dedication to the result depends on facilities, medical science advances and the discovery of viruses and the complications of blood transfusion in a period of production and supply. One cannot expect a duty beyond its abilities. It is not rational to speak of the state's responsibility for what may be happen in future because it may not be a loss conventionally or conceptually; the main condition for loss is its capability of being predicted and its certainty. Virus transmission, incidence of delayed complications of infections, and the viruses HIV, HCV, and HIV (passed incubation period) are subject to compensation either the state sees itself exempted from compensation according to Article 11 of Civil Liability Law or the aggrieved person is in a gradual death and expect compensation. The compensation may be financial, material, and spiritual and he may believe that the surplus compensation to the atonement is not enough for him. It should be noted that the government should act as good and just ruler in the exercise of its sovereignty. It seems Article 11 of this law should be adjusted and interpreted according to Articles 22, 40, and 171 of the Constitution, law on Protection of Consumers' Rights (2009), FIPPA foreign investment (2002), The International Covenant on Civil and Political Rights (1975), rights of citizenship, protecting the right to life, and certain rules of jurisprudence such as 'no damage and no harmful act exists in Islam', 'the one who take advantages should accept losses 'and 'warning'. Assumption of government's lack of liability should be limited to legal cases and obstacles such as force majeure, fault by the injured, giving information and alerts about blood transfusion complications by mass media. In this manner, the 
victims can refer to legal authorities and competent court to enforce their rights. In addition, In the event of criminal complaint, they have the right to demand losses resulting from crime; the courts will investigate the case due to their exceptional authority and their competency to address the case.

\section{References}

Abulhamd, A. (1991). Administrative law of Iran (1st ed.). Tehran, Toos Publication.p. 824.

Adibi Motlagh, B. et al. (2007). Laboratory Biosafety Manual (3rd ed.). Tehran, Iran Blood Transfusion Organization Research Center. p. 156.

Akbari, M. (2005). The concept of civil liability of legal persons. Justice Monthly, Tehran, pp.50, 17-18.

Akhavai, M., \& Kashani, M. (2001). Victims'obligation to minimize the damage with an emphasis on the rights of England and America. Journal of Humanities and Social Sciences of Shiraz University, 17(1), 56.

Al-Terab losi, Q. (1991). Al-mohazab (Vo1. 24, 3rd ed.). Revival of Arab Heritage, p. 156.

Al-Wajiz. (2007). Qtd in: Mahamasani, Sobhi Rajab. The philosophy of legislation in Islam (1st ed.). Translated by Is mail Golestani, Tehran, Publication of Thought Effects, p. 241.

Ashoori, M. (1997). Criminal Justice (1st ed.). Tehran: Treasure of Knowledge Publisher. pp. 39, 80-81.

Ashoori, M. (2007). Criminal Procedure Code (Vol. 1, 12th ed.). Tehran: Samt Publication, pp. 236-237.

Badini, H. (2005). The philosophy of civil liability (1st ed.). Tehran, Publishing Corporation, p. 28-29.

Badini, H. (2008). Rules governing simultaneous application of the compensation systems (civil liability insurance and Social Security). Legal Journal of Law and Political Science Faculty of Tehran University, Tehran, 38(2), 61.

Barikloo, A. (2006). Civil liability (1st ed.). Tehran, Mizan publication, p. 22.

Dalvand, F. (2007). Division of civil liability (1st ed). Isfahan, Dadyar Pub lication, p. 17.

Habibi, M. (2005). Validity of a judged case. Tehran, Knowledge Magazine, 93, p. 62.

Hosseini Nejad, H. (1998). Civil liability (1st ed).Tehran, Publication of Shahid Beheshti University, p. 17.

Ismaili, I. (1994). Buying and selling blood. New Exploration of Islamic jurisprudence, Tehran, fall, 1, p p.150-151.

Jafari Langroodi, M. (1999). Detailes in Law Terminology (Vol. 2.). Treasure of Knowledge Publication, 6, p.482.

Jafari Langroodi, M. (2001). Law Terminology (11th ed.). Tehran, Treasure of Knowledge Publication, p. 642.

Jafaritabar, H. (2010). Civil liability of goods (1st ed.). Tehran, Justice Publication, p. 77.

Jourdain, P. (2007). Analysis of judicial procedures in the field of civil liability. (1st ed) Translated by Majid Adib. Tehran, Mizan Publication, pp.17-18.

Katouzian, N. (2001). The nature and scope of atonement (losses resulting from crime). Journal of Central Bar Association, Tehran, 6(1371-72), 26-28.

Mehman Navazan, R. (2008). Compensable damages in Iranian law (1st ed.). Tehran, Publication of Thought Effects. p. 83.

Mohammad Khani, H. (2007). The government's civil liability at the court of justice (1st ed.). Tehran, Be'sat publication, p. 98.

Mohammad Pour, E. (1997). Legal analysis of criminal laws (Vol. 1, 2nd ed.). Tehran, Treasure of Knowledge Publication, p. 52.

Nain i, M. (1997). Munyat al-Tolab (Vol. 3, 3rd ed.). Qo m, Almortazawiya School, p. 348.

Najafi Fatahi, S. (2005). Material compensation for moral damages in the Iranian legal system. Journal of Bar Association, 168, 161.

Najafi, M. (1981). Jawāhir al-kalām fì sharh Sharā'i' al-Islām (7th ed.). Tehran, Islamiya Library ,p 37.

Noori, H. et al. (2001). Principles of blood transfusion (1st ed.). Tehran, Charity Foundation for Special Diseases Publication, $\mathrm{p} 82$.

Qasemzadeh, M. (2008). Obligations and civil liability without a contract (3rd ed.). Tehran, Mizan Pub lication, p. 72. 
Safaei, H., \& Ghasemzadeh, M. (2001). The civil rights of individuals and incapable persons (6th ed.). Tehran, Samt Publication, p. 6.

Safari, M. (1998). Deception and its consequences (conceit rule) in civil law and Imamiyeh religious Jurisprudence (1st ed.). Tehran, Mizan \& Dadgostar Publications. p. 13.

Seifi, J. (2005). The sentence called Hemophilia Case; new approach to state civil liability in the precedent of Iran. Tehran, Shahid Beheshti University Law Journal, 8.

Seraj, M. (1989). Zeman Al-o'dwan fi Al-figh e Al-islami. Cairo, House of Culture for Publishing and Distribution. 6, 189.

Shahidi, M. (2004). Principles of Contracts and Commitments (3rd ed.). Tehran, Majd Publication, p. 32.

Sherafat Pey ma, M. (2007). The concept of externat cause and its impact on civil liability: A comparative study. $\mathrm{PhD}$ dessertation, Tarbiat Modares University, 82-95.

Tavasoli Jahromi, M. (2003). Emergency impact on civil liability. Journal of law and political science at Tehran University, Tehran, 60, 65.

\section{Copyrights}

Copyright for this article is retained by the author(s), with first publication rights granted to the journal.

This is an open-access article distributed under the terms and conditions of the Creative Commons Attribution license (http://creativecommons.org/licenses/by/4.0/). 